\title{
Severe aplastic anaemia following the use of hair dye: report of two cases and review of literature
}

\author{
J.E. Hopkins and A. Manoharan \\ Department of Clinical Haematology, St. George Hospital, Kogarah 2217, Sydney, N.S.W., Australia
}

\begin{abstract}
Summary: We describe two female patients aged 31 and 62 y who developed severe aplastic anaemia following the use of hair dye containing para-toluenediamine. One received a bone marrow transplant but died after developing graft versus host disease and severe opportunistic infection. The second responded to treatment with methylprednisolone, oxymetholone and antithymocyte globulin and $3 \mathrm{y}$ later she has a normal blood count apart from mild thrombocytopenia.

In this paper we also review previously described case reports of aplastic anaemia apparently associated with the use of hair dye.
\end{abstract}

\section{Introduction}

Hair dye containing para-toluenediamine and closely related compounds, has been linked to gastrointestinal and neurological toxicity (Close, 1932), mutagenicity (Ames et al., 1975; Searle et al., 1975) and macrocytic anaemia (Baldridge, 1935; Bomford \& Rhoads, 1941), as well as several case reports of aplastic anaemia (Baldridge, 1935; Thompson, 1965; Hamilton \& Sheridan, 1976; Toghill \& Wilcox, 1976). In this report we describe two further cases of probable hair dye induced severe aplastic anaemia.

\section{Case histories}

\section{Case 1}

A 31 year old housewife presented in August, 1978 with aplastic anaemia. Six weeks before presentation she underwent a laparoscopic tubal ligation under routine general anaesthesia. Full blood count was normal at this time. On returning home the patient used a hair dye containing para-toluenediamine and 2 weeks later noticed epistaxis. In the following 2 weeks, bruising, stomal ulceration and recurrent skin infections developed. She was on no medications before presentation.

On examination she had buccal ulceration, mucosal petechiae and scattered ecchymoses of the skin, with a positive Hess test. There were a few minimally enlarged lymph nodes in the axillae and groin but no hepatosplenomegaly. A full blood count revealed

Correspondence: A. Manoharan, M.D.

Accepted: 24 May 1985 haemoglobin $10.3 \mathrm{~g} / \mathrm{dl}$, white cell count $2.8 \times 10^{9} / 1$, neutrophils $0.6 \times 10^{9} / 1$, platelet count $20 \times 10^{9} / 1$ and reticulocyte count $0.1 \%$, with these counts subsequently falling into the range of severe aplastic anaemia (Camitta et al., 1976). Serum biochemistry, liver function tests, antinuclear factor, LE cells, direct antiglobulin and Ham's tests were all normal or negative. Bone marrow aspirate showed marked hypoplasia of all haemopoietic series with a relative increase in lymphocytes and plasma cells; trephine biopsy confirmed severe hypoplasia and revealed normal reticulin with no infiltration.

Six weeks after presentation an ABO-HLA compatible bone marrow transplant from the patient's sister was performed. This was complicated 4 weeks later by graft versus host disease. High dose steroids were commenced; however, severe opportunistic infection developed leading to the patient's death.

\section{Case 2}

A 62 year old housewife was admitted in May, 1981 after a one week history of spontaneous bruising. She was on no regular medications but had used naproxen for $3 \mathrm{~d}, 2$ weeks before presentation. She was a regular user of hair dye containing para-toluenediamine, having last used it 2 weeks before admission. There was no history of intercurrent viral illness.

On examination she looked well except for widespread ecchymoses and palatal petechial haemorrhages. She had no hepatosplenomegaly and no lymphadenopathy. Haemoglobin was $10.1 \mathrm{~g} / \mathrm{dl}$, white cell count $1.8 \times 10^{9} / 1$, neutrophils $0.036 \times 10^{9} / 1$, platelet count $3 \times 10^{9} / 1$ and reticulocyte count $0.3 \%$. Liver 
function tests, biochemistry, direct antiglobulin test, Ham's test and sucrose lysis and antinuclear factor were all normal or negative. Bone marrow aspirate and trephine biopsy were markedly hypocellular with no evidence of infiltration.

She was treated with packed cell and platelet transfusions, methylprednisolone (intravenously, commencing at $20 \mathrm{mg} / \mathrm{kg} / \mathrm{d}$ for $3 \mathrm{~d}$, reducing at $3 \mathrm{rd}$ daily intervals by $50 \%$ ) and antithymocyte globulin $(12 \mathrm{mg} / \mathrm{kg}$ intravenously on alternate days for 5 doses); 2 weeks later oxymetholone $(3 \mathrm{mg} / \mathrm{kg} / \mathrm{d}$ orally) was added. Over the next 6 months her haematological parameters improved to normal except for a mild thrombocytopenia, platelets stabilizing at $110 \times 10^{9} / 1$. Oxymetholone was gradually reduced and ceased 18 months after presentation. She remains well and on no medications.

\section{Discussion}

In both of these cases there was exposure to hair dye 2 to 4 weeks before presentation. No other aetiological factor was identified in either patient. In addition to these 2 cases there are 4 other published cases of aplastic anaemia associated with hair dye use (Baldridge, 1935; Thompson, 1965; Hamilton \& Sheridan, 1976; Toghill \& Wilcox, 1976); these are summarized in Table I. This Table illustrates a wide age range of patients; from 17-62 y. All cases, not surprisingly, occurred in females. Three out of 6 patients died, two of them due to intracerebral haemorrhage, the third dying from infection following bone marrow transplantation. The remaining 3 patients were alive at follow-up, between 5 months and 3 y after presentation. The treatments varied widely and some are now considered of no proven value. Unfortunately in 3 of the cases there is insufficient documentation to fully assess the severity of the aplastic anaemia.

Both of our cases fall into the group of severe aplastic anaemia, which carries an overall mortality rate of $91 \%$ in the first 4 months after presentation (Lynch et al., 1975). Conventional treatment, comprising haematological support, steroids and androgens are known to be of little value in patients with severe aplastic anaemia (Camitta et al., 1976; 1979). Significant improvements in survival have been obtained with bone marrow transplantation (Camitta et al.,

Table I Hair dye-induced aplastic anaemia

\begin{tabular}{|c|c|c|c|c|}
\hline $\begin{array}{l}\text { Patient } \\
\text { Age/Sex }\end{array}$ & $\begin{array}{l}\text { Blood counts } \\
\text { on presentation }\end{array}$ & Treatment & Follow-up & Reference \\
\hline 1. $42 \mathrm{y} / \mathrm{F}$ & $\begin{array}{c}\text { Hb } 4 \mathrm{~g} / \mathrm{dl} . \\
\text { WCC } 0.002 \times 10^{9} / 1 \\
\text { Neutrophils } 0.001 \times 10^{9} / 1 \\
\text { Platelets } 0.02 \% \text { by volume } \\
\text { Retics } 1.6 \%\end{array}$ & $\begin{array}{l}\text { coagulin } \\
\text { injections }\end{array}$ & $\begin{array}{l}\text { Well } 6 \text { months } \\
\text { later }\end{array}$ & Baldridge, 1935 \\
\hline 2. $17 \mathrm{y} / \mathrm{F}$ & $\begin{array}{c}\text { Hb } 72 \% \\
\text { WCC } 2.0 \times 10^{9} / 1 \\
\text { Platelets } 1 \times 10^{9} / 1\end{array}$ & $\begin{array}{c}\text { prednisone } \\
\text { phytohaemagglutinin } \\
\text { bone marrow } \\
\text { transplants } \times 2\end{array}$ & $\begin{array}{l}\text { Died } 1 \text { month later } \\
\text { from intracerebral } \\
\text { haemorrhage }\end{array}$ & Thompson, 1965 \\
\hline 3. $54 \mathrm{y} / \mathrm{F}$ & Not recorded & $\begin{array}{l}\text { prednisolone } \\
\text { oxymetholone } \\
\text { ethamsylate }\end{array}$ & $\begin{array}{l}\text { Well } 5 \text { months } \\
\text { later }\end{array}$ & $\begin{array}{c}\text { Hamilton \& Sheridan, } \\
1976\end{array}$ \\
\hline 4. $52 \mathrm{y} / \mathrm{F}$ & $\begin{array}{c}\mathrm{Hb} 9.9 \mathrm{~g} / \mathrm{dl} \\
\text { WCC } 8.5 \times 10^{9} / 1 \\
\text { Platelets } 8 \times 10^{9} / 1\end{array}$ & $\begin{array}{l}\text { prednisolone } \\
\text { oxymetholone }\end{array}$ & $\begin{array}{c}\text { Died } 6 \text { months } \\
\text { later from intra- } \\
\text { cerebral haemorrhage }\end{array}$ & $\begin{array}{c}\text { Toghill \& Wilcox } \\
1976\end{array}$ \\
\hline 5. $31 \mathrm{y} / \mathrm{F}$ & $\begin{array}{c}\text { Hb } 10.3 \mathrm{~g} / \mathrm{dl} \\
\text { WCC } 2.8 \times 10^{9} / 1 \\
\text { Neutrophils } 600 \times 10^{9} / 1 \\
\text { Platelets } 20 \times 10^{9} / 1 \\
\text { Retics } 0.1 \%\end{array}$ & $\begin{array}{l}\text { bone marrow } \\
\text { transplant }\end{array}$ & $\begin{array}{l}\text { Died } 6 \text { months later } \\
\text { from opportunistic } \\
\text { infection }\end{array}$ & This report \\
\hline 6. $62 \mathrm{y} / \mathrm{F}$ & $\begin{array}{c}\text { Hb } 10.1 \mathrm{~g} / \mathrm{dl} \\
\text { WCC } 1.8 \times 10^{9} / 1 \\
\text { Neutrophils } 0.03 \times 10^{9} / 1 \\
\text { Platelets } 3 \times 10^{9} / 1 \\
\text { Retics } 0.3 \%\end{array}$ & $\begin{array}{l}\text { methylprednisolone } \\
\text { oxymetholone } \\
\text { antithymocyte } \\
\text { globulin }\end{array}$ & Well 3 y later & This report \\
\hline
\end{tabular}

Hb: haemoglobin; WCC: white cell count; Retics: reticulocyte count. 
1976; 1979) and, more recently, antithymocyte globulin (Speck et al., 1981; Champlin et al., 1983; Fairhead et al., 1983; Miller et al., 1983). As both of our patients had severe aplastic anaemia, active treatment was initiated, the first patient receiving a bone marrow transplant. The second patient, however, was not suitable for transplantation because of age; treatment comprised of methylprednisolone, androgens and antithymocyte globulin with a good haematological response. This is the first report of probable hair dye induced aplastic anaemia successfully treated with antithymocyte globulin.

The postulated aetiological agent, hair dye, contains para-tolvenediamine, a benzene derivative; benzenes themselves have been closely linked to aplastic anaemia (Cavignaux, 1962). As with any case of aplastic anaemia, it is difficult to prove para-tolvenediamine as the aetiological factor. However, in the

\section{References}

AMES, B.M., KAMMEN, H.O. \& YAMASAKI, E. (1975). Hair dyes are mutagenic: identification of a variety of mutagenic ingredients. Proceedings of the National Academy of Sciences of the United States of America, 72, 2423.

BALDRIDGE, C.W. (1935). Macrocytic anemia with aplastic features following the application of synthetic organic hair dye. American Journal of the Medical Sciences, 189, 759.

BOMFORD, R.R. \& RHOADS, C.P. (1941). Refractory anaemia. Quarterly Journal of Medicine, 10, 175.

CAVIGNAUX, L. (1962). Confirmed intoxications (Fr) Cachiens de medicine interprofessionelle, 2, 28.

CAMITTA, B.M., THOMAS, E.D., NATHAN, D.G., SANTOS, G., GORDON-SMITH, E.C., GALE, R.P., RAPPEPORT, J.M. \& STORB, R. (1976). Severe aplastic anemia: a prospective study of the effect of early marrow transplantation on acute mortality. Blood, 48, 63.

CAMITTA, B.M., THOMAS, E.D., NATHAN, D.G., GALE, R.P., KOPECKY, K.J., RAPPEPORT, J.M., SANTOS, G., GORDON-SMITH, E.C. \& STORB, R. (1979). A prospective study of androgens and bone marrow transplantation for treatment of severe aplastic anemia. Blood, 53, 504.

CHAMPLIN, R., HO, W. \& GALE, R.P. (1983). Antithymocyte globulin treatment in patients with aplastic anemia. New England Journal of Medicine, 308, 113.

CLOSE, W.J. (1932). A case of poisoning from hair dye. Medical Journal of Australia, 1, 53. cases described, no other cause was found. Considering the widespread use of hair dye containing this compound, the complication must be rare and is likely to be an idiosyncratic one. However, these additional case reports emphasize the need for continuing scrutiny and further investigation of these possible marrow toxins, as well as their inclusion in questioning patients with apparently idiopathic aplastic anaemia.

\section{Acknowledgements}

We wish to thank Professor W.R. Pitney for reviewing the manuscript and Mrs M. Jenkins and Mrs E. Hunt for their secretarial help.

FAIRHEAD, S.M., CHIPPING, P.M. \& GORDON-SMITH, E.C. (1983). Treatment of aplastic anaemia with antilymphocyte globulin. British Journal of Haematology, 55, 7.

HAMILTON, S. \& SHERIDAN, J.G. (1976). Aplastic anaemia and hair dye. British Medical Journal, 1, 834.

LYNCH, R.E., WILLIAMS, D.M., READING, J.C. \& CARTWRIGHT, G.E. (1975). The prognosis in aplastic anemia. Blood, 45, 517.

MILLER, W.J., BRANDA, R.F., FLYNN, P.J., HOWE, R.B., RAMSAY, N.K.C., CONDIE, R.M. \& JACOB, H.S. (1983). Antithymocyte globulin treatment of severe aplastic anaemia. British Journal of Haematology, 55, 17.

SEALE, C.E., HARNDEN, D.G., VENITT, S. \& GYDE, O.H.B. (1975). Carcinogenicity of mutagenicity tests of some hair colourants and constituents. Nature, 255, 506.

SPECK, B., GRATWOHL, A., NISSEN, C., LEIBUNDGUT, U., RUGGERO, D., OSTERWALDER, B., BURRI, H.P., CORNU, P. \& JEANNET, M. (1981). Treatment of severe aplastic anaemia with anti-lymphocyte globulin or bone marrow transplantation. British Medical Journal, 282, 860.

TOGHILL, P.J. \& WILCOX, R.G. (1976). Aplastic anaemia and hair dye. British Medical Journal, 1, 502.

THOMPSON, S.J. (1965). Aplastic anaemia. Nursing Times, 61, 12. 